\title{
Exploration of Experiencing Teaching Modes of College Public English Curriculum Based on Cognitive Neuroscience*
}

\author{
Feng $\mathrm{Gu}^{1}$ \\ Chaohu University
}

\begin{abstract}
Under the background of the development of cognitive neuroscience, the disciplinary nature and structure of linguistics should be re-examined in order to clarify the hierarchical relationship of the research direction in linguistics. Based on the methodology of complex scientific research and the development model of interdisciplinary knowledge, this study takes the experiencing teaching reform of public English curriculum in colleges and universities as an example, discusses the necessity of systematically integrating linguistic studies in different dimensions, and proposes a tentative plan for the reform of graduate curriculum system in linguistics. The characteristic of experiential English teaching based on neuroscience is to make students participate in learning actively and become the center and initiative participants of learning by simulating the real situation. By creating different future jobs and simulating situations, students of different specialties can learn English through experience, which is conducive to the students' natural integration into teaching and active learning of English knowledge and practical skills required in their future employment.
\end{abstract}

\section{Keywords}

Cognitive Neuroscience • College Public English Course • Experiential Teaching • Language Subject

\footnotetext{
* I would like to thank Anhui Provincial Quality Engineering Research Projects "College English Teaching Team (Project No. 2015jxtd035)" and "College English Deep Teaching Reform and Practice (Project No. 2016jyxm0690)" which supported my work on this study.

${ }^{1}$ Correspondence to: Feng Gu (MA), School of Foreign Languages, Chaohu University, Chaohu 238000, China. Email: gufeng1218@sina.com

Citation: Gu, F., (2018). Exploration of Experiencing Teaching Modes of College Public English Curriculum Based on Cognitive Neuroscience. 18(5), 1775-1783. http://dx.doi.org/10.12738/estp.2018.5.077
} 
Cognitive science is an advanced and cutting-edge science that explores the human brain or mental working mechanism. Its internationally accepted disciplinary structure is composed of knowledge networks interwoven with linguistics, neuroscience, philosophy, psychology, anthropology, artificial intelligence and pedagogy (Schaffner, Schiefele \& Ulferts. 2013; Kurpis, \& Hunter, 2017). From the level framework of linguistics and methodology in the perspective of cognitive science, we can see that the research direction of linguistics is not separate and independent from each other, but around the two fundamental purposes of constructing hypotheses and verifying hypotheses, forming an organic whole or system of interaction (Johnson, Charchanti, \& Troupis, 2012). In addition, different levels provide different validity of evidence, and between any two levels, the research of the upper level can often be used as the construction layer of hypothesis, and the research of next level provides evidence support for the upper level, and thus they will also generate interaction (Hung, Huang, \& Hwang, 2014). For example, the hypothesis proposed by psycholinguists needs to be supported by the evidence of neurolinguistics, and the findings of psycholinguistics can be used as evidence of hypotheses in sociolinguistics and human linguistics.

\section{Research on Language Integration under the Interdisciplinary Development}

\section{Interdisciplinary knowledge development model}

The classification of traditional disciplines makes some disciplines which are intrinsically connected separate from each other, and even some cross-research fails to realize the integration effect of knowledge fusion (Sung, Hwang, Lin, \& Hong, 2017). For example, with the development of cognitive neuroscience, the researches in traditional psychology, pedagogy, linguistics and others develop from philosophical thinking, behavioral and psychological level into the level of neuroscience, becoming more scientific. The fusion of these disciplines will lead to new research problems, directions and even disciplines. This also makes the future development of disciplines can not only meet the interdisciplinary and multi-disciplinary research (see Figure 1), but also needs a variety of disciplines to promote the formation and development of the field of interdisciplinary research.

The interdisciplinary research is about a knowledge development model proposed by Japanese scholar Hideaki Koizumi, who thinks that the development of disciplines toward specialization and refinement also brings about two disadvantages: one is that each discipline produces a great deal of knowledge, but it is difficult to manage and integrate it systematically; the other is that the knowledge barrier among disciplines gradually becomes bigger and thicker, but the division among them may be short of logic. Therefore, a dynamic metastructure is needed to promote the integration and division of disciplines in order to integrate many disciplines to solve some difficult problems (Lee, 2012). When the interdisciplinary research becomes mature, it enters into a dynamic meta-structure and becomes a definite science, which can contribute to the cross-development of the discipline in the future (Ma, Steger, Doolittle \& Stewart, 2018). Hideaki Koizumi believes that with the establishment of the bridge between related disciplines, a new sub-discipline with unique method and organization structure will emerge gradually. Once the new discipline is formed, it can enter the development process of dynamic meta-structure and play a role in the further development of the interdisciplinary research 
as an established discipline. What's more, it can also have an impact on the parent discipline by providing feedback, as shown in Figure 2.

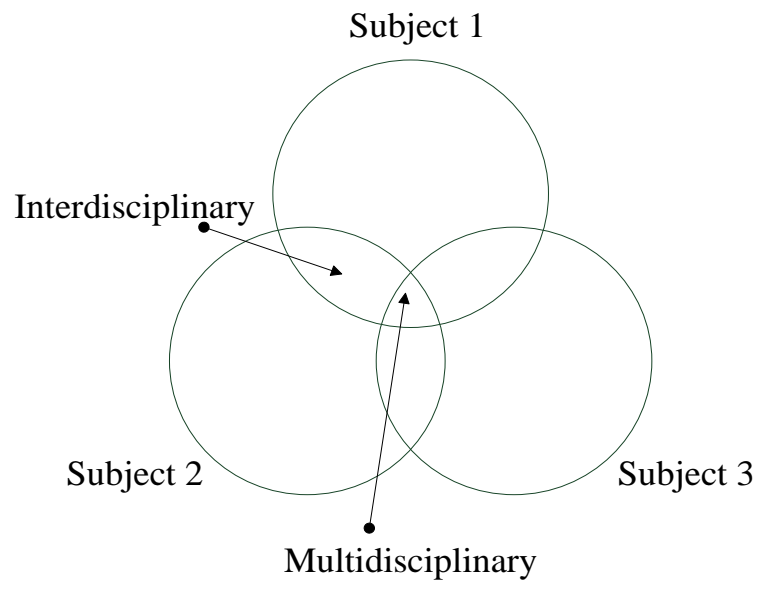

Figure 1. Interdisciplinary relationship in interdisciplinary and multidisciplinary research.

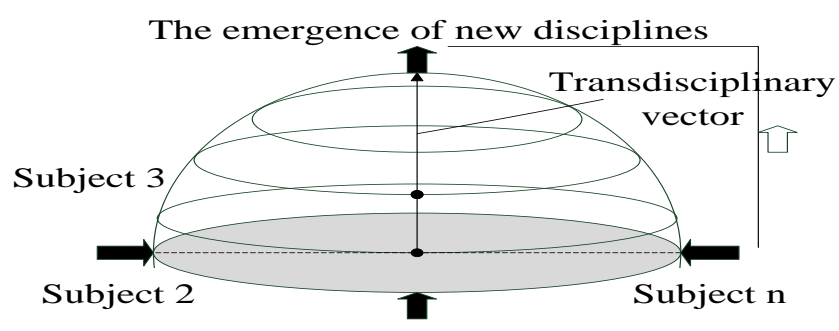

Subject 1

Figure 2. Interdisciplinary knowledge development model.

In addition, this process of fusion and division co-exists in many disciplines at the same time. The parent discipline can produce several sub-disciplines at the same time, and the sub-disciplines can also produce new sub-disciplines, and so on, presenting a dynamic knowledge development mode (Tang, 2016). It can be seen that the knowledge development model of the interdisciplinary regards human knowledge itself as a complex system, which is characterized by non-linearity, self-organization, feedback, emergence and openness.

\section{The Disciplinary Structure of Linguistics from the Perspective of Cognitive Science}

In addition to theoretical linguistics, descriptive linguistics and applied linguistics, we believe that linguistic discipline structure should include linguistic philosophy, and that linguistics, as an open system, interacts and integrates with other relevant disciplines (See Figure 3). 


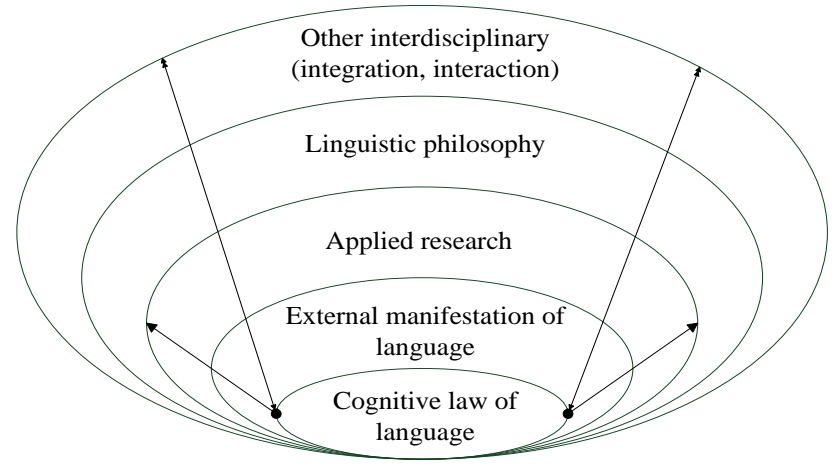

Figure 3. Linguistic structure.

The first is theoretical linguistics: the study of the cognitive mechanism of language based on cognitive neuroscience, including the use of brain damage, brain stimulation, and brain imaging techniques to study the distribution of speech and semantics in the brain region, nerve transmission, functional representation and so on, so as to explain the nature, origin and acquisition of language. The second is descriptive linguistics, which regards language as a symbolic system of social communication. In addition to traditional research in humanities and social sciences, it is necessary to develop new research fields in combination with mathematics (Chen \& Liu, 2016; Chen, Lu \& Liu, 2018). In addition, there are also applied linguistics: the practical application of the theoretical achievements of internal and external linguistics in the fields of language teaching, translation, dictionary compilation and so on (Brown, Willett, Goldfine, \& Goldfine, 2018; Vandsburger, Duncan-Daston, Akerson, \& Dillon, 2010). The last part is the philosophy of linguistics, similar to philosophy of mathematics and philosophy of physics, which reflects and criticizes the basis of epistemology and methodology of linguistic theories, examines the basic hypothesis of theories, the rationality of logical argument and the reliability and validity of argument, and promotes the development, perfection and innovation of linguistic theories.

\section{Design and Implementation of Public English Experiential Teaching in Universities Based on Neuroscience}

\section{Teaching model framework}

In the experience teaching of college public English based on neuroscience, the practical experience mainly originates from the workplace simulation focusing on the ability of post English. This teaching mode can be decomposed into the circular mode of practical experience-observation and thinking-abstract induction-active experiment, which can be described in Figure 4: 
Practical experience: case teaching, flipping classroom learning, field trips, hands-on experience
Active experiment: workplace simulation dialogue, professional training room training, participation in exhibitions, immersive projects
Observation and thinking: pairing, group discussion, group activities, group discussions, observation

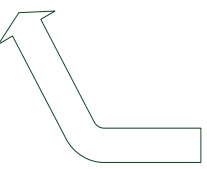

Abstract induction: the transfer and sharing of abstract language combined with the actual workplace environment

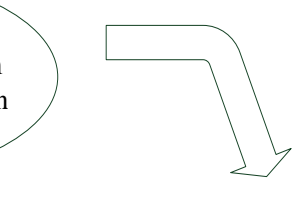

Figure 4. Learning cycle diagram.

\section{Investigation on the selection and learning status of experimental and control classes}

First of all, the questionnaire is aimed at Class I and Class II with the same major in a certain university. There are 108 students in the two classes, with an average age of 20 years old. One hundred students are randomly selected, with each corresponding to a questionnaire, and 100 questionnaires are recovered, with 98 effective questionnaires and an effective rate of $98 \%$. The survey found that $71 \%$ of the students said the class was uninteresting. Subsequently, the same English proficiency test was conducted for the two classes (pre-test), and the pre-test data are shown in Table 1:

Table 1

Comparison of Pre-test Data between Experimental Class and Control Class

\begin{tabular}{lccccc}
\hline class & Number of students & Mean & Standard deviation & T value & P value \\
\hline Control class & 58 & 77.15 & 6.34 & \multirow{2}{*}{-3.24} & \multirow{2}{*}{0.14} \\
Experimental class & 40 & 78.45 & 6.58 & & \\
\hline
\end{tabular}

By independent sample t-test, the mean value of the control class is 77.15 and the standard deviation is 6.34 ; the mean value of the experiment class is 78.45 and the standard deviation is 6.58 . The comparison between the two groups shows that there is no significant difference between the experiment class and the control class. That's, there is no significant difference in English scores between the experimental class and the control class. Comparing the data, $\mathrm{T}$ value is -3.24 and $\mathrm{p}$ value is $0.14>0.05$, that's, there was no significant difference between the two classes, and the English proficiency of the two classes is close to the same.

\section{Comparison of learning effects between experimental class and control class}

The first is the questionnaire analysis and investigation results, as shown in Table 2 and Table 3.

Table 2

Gender Survey Data Statistics

\begin{tabular}{lcc}
\hline Select item & People number & Percentage \\
\hline Male & 45 & $46 \%$ \\
Female & 53 & $54 \%$ \\
Total & 98 & $100 \%$ \\
\hline
\end{tabular}


Table 3

Population Survey Data Statistics

\begin{tabular}{lcc}
\hline Select item & People number & Percentage \\
\hline Male & 40 & $41 \%$ \\
Female & 58 & $59 \%$ \\
Total & 98 & $100 \%$ \\
\hline
\end{tabular}

Next is the questionnaire item investigation analysis. The questionnaire consists of four dimensions: students' learning motivation, teaching methods, students' learning initiative and teaching evaluation, which are analyzed in detail as below. Table 4 and Table 5 show the differences among the four dimensions, the mean value and standard deviation of each item in each dimension of the pre-test experimental class and control class.

Table 4

Control Class Dimension Description Statistics

\begin{tabular}{lccccc}
\hline Dimension & $\begin{array}{c}\text { Number } \\
\text { of items }\end{array}$ & $\begin{array}{c}\text { Minimum } \\
\text { value }\end{array}$ & $\begin{array}{c}\text { Maximum } \\
\text { value }\end{array}$ & Mean & $\begin{array}{c}\text { Standard } \\
\text { deviation }\end{array}$ \\
\hline Students' learning motivation & 9 & 2.11 & 3.69 & 3.04 & 1.15 \\
Teaching method & 12 & 2.65 & 4.21 & 3.41 & 1.42 \\
Students' learning initiative & 6 & 2.51 & 5.02 & 3.75 & 2.44 \\
Teaching evaluation & 12 & 3.54 & 4.96 & 4.26 & 1.36 \\
\hline
\end{tabular}

In this robust analysis, the method of Likert scale is adopted for scoring. The higher the score of each dimension is, the more stable the students are on the item. Through the comparison between the experimental class and the control class, the experimental class is slightly higher than the control class in terms of students' learning motivation, and the mean value of the experimental class is 3.54 and that of the control class is 3.04 ; in terms of teaching method, the mean value of the control class is 3.41, and that of the experimental class is 4.31, which is greatly higher than the former; in terms of students' learning initiative, the mean value of the experimental class is 4.08 , and that of the control class is 3.75 , with the former slightly higher than the latter; in terms of teaching evaluation, the mean value of the experimental class is 4.45 , and that of the control class is 4.26, which differ slightly. The results of investigation and analysis show that the experimental class is much higher than the control class in the students' learning motivation, teaching methods and students' learning initiative, but slightly different from the control class in the teaching evaluation.

Table 5

Experimental Class Dimension Description Statistics

\begin{tabular}{lccccc}
\hline Dimension & $\begin{array}{c}\text { Number of } \\
\text { items }\end{array}$ & $\begin{array}{c}\text { Minimum } \\
\text { value }\end{array}$ & $\begin{array}{c}\text { Maximum } \\
\text { value }\end{array}$ & Mean & Standard deviation \\
\hline Students' learning motivation & 9 & 2.94 & 4.06 & 3.54 & 1.02 \\
Teaching method & 12 & 3.88 & 4.98 & 4.31 & 1.18 \\
Students' learning initiative & 6 & 3.02 & 5.00 & 4.08 & 1.97 \\
Teaching evaluation & 12 & 4.04 & 4.97 & 4.45 & 0.95 \\
\hline
\end{tabular}

Next, the analysis of each dimension and each dimension of the experimental class and the control class will be performed by a separate sample of each dimension. Students' learning motivation is the most original purpose and motivation for English learning in the control class and the experimental class. The data will be explained in detail below. See Tables 6, 7, 8 and 9. 
Table 6

Students' Learning Motivation Group Statistic

\begin{tabular}{lccccc}
\hline & Class & Number & Mean & $\begin{array}{c}\text { Standard } \\
\text { deviation }\end{array}$ & $\begin{array}{c}\text { Standard error } \\
\text { of mean }\end{array}$ \\
\hline \multirow{2}{*}{ Students' learning motivation } & Experimental class & 40 & 3.51 & 1.02 & 0.24 \\
& Control class & 58 & 3.01 & 1.14 & 0.34 \\
\hline
\end{tabular}

Table 7

Teaching Method Group Statistics

\begin{tabular}{lccccc}
\hline & Class & Number & Mean & Standard deviation & $\begin{array}{c}\text { Standard error } \\
\text { of mean }\end{array}$ \\
\hline \multirow{2}{*}{ Teaching method } & Experimental class & 40 & 4.35 & 1.12 & 0.24 \\
& Control class & 58 & 3.41 & 1.58 & 0.47 \\
\hline
\end{tabular}

Table 8

Students' Learning Initiative Group Statistics

\begin{tabular}{lccccc}
\hline & Class & Number & Mean & $\begin{array}{c}\text { Standard } \\
\text { deviation }\end{array}$ & $\begin{array}{c}\text { Standard error } \\
\text { of mean }\end{array}$ \\
\hline \multirow{2}{*}{ Students' learning initiative } & Experimental class & 40 & 4.02 & 1.96 & 0.42 \\
& Control class & 58 & 3.74 & 2.47 & 0.69 \\
\hline
\end{tabular}

Table 9

Teaching Evaluation Group Statistics

\begin{tabular}{lccccc}
\hline & Class & Number & Mean & $\begin{array}{c}\text { Standard } \\
\text { deviation }\end{array}$ & Standard error of mean \\
\hline \multirow{2}{*}{ Teaching evaluation } & Experimental class & 40 & 4.48 & 0.97 & 0.24 \\
& Control class & 58 & 4.26 & 1.32 & 0.36 \\
\hline
\end{tabular}

\section{Teaching effect analysis}

The pre-test show that the experimental class and the control class have the close English proficiency before the teaching experiment. Then in the control class, the traditional English teaching mode is adopted, and in the experimental class, and the experiential teaching mode of college English based on post professional ability is adopted to carry out the daily teaching. After a two-semester teaching experiment is conducted for two classes, the English proficiency test (post-test) with the same difficulty is conducted for two classes, and the specific data are shown in Table 10:

Table 10

Experimental Class Dimension Description Statistics

\begin{tabular}{lccccc}
\hline Class & Number of students & Mean & Standard deviation & T value & P value \\
\hline Control class & 58 & 62.14 & 8.49 & \multirow{2}{*}{0.52} & \multirow{2}{*}{0.001} \\
Experimental class & 40 & 75.58 & 5.87 & & \\
\hline
\end{tabular}

Through independent sample t-test, the mean value of the control class is 62.14 , and the mean value of the experimental class is 75.58 . The comparison between the two groups of data shows that there is a big difference between the experimental class and the control class. The English score of the experimental class is 13 points higher than that of the control class. Standard deviation of the control class is 8.49 , and that of the experimental 
class is 5.87 , where $\mathrm{t}$ is $-3.52, \mathrm{p}$ is $0.001<0.05$, that's, there is a significant difference in English scores between the two classes.

From the above data, it can be seen that after a two-semester teaching experiment, the English scores of the two classes with almost the same English proficiency in the pre-test are greatly different with the English score of the experimental class which adopts the experiential teaching mode of college English based on neuroscience is much higher than that of the control class which adopts the traditional English teaching mode.

\section{Conclusion}

The above analysis shows the obvious differences between the experimental class and the control class in students' learning motivation, teaching methods, learning initiative, teaching evaluation and teaching effect. From this result, it can be seen that the students' academic achievement has been improved obviously after carrying out the English experiential teaching mode based on neuroscience. At the same time, the development of this effective teaching mode is beneficial to improve students' learning initiative and motivation. Students are more inclined to initiatively learn knowledge and actively interact with teachers before and after class. In addition, students have more confidence in their own learning conditions, and at the same time, their "sense of self-efficacy" has also been improved. On the other hand, teachers in this teaching mode also play their leading role to the greatest extent, and thus constantly improve their own teaching quality.

\section{References}

Brown, C., Willett, J., Goldfine, R., \& Goldfine, B. (2018). Sport management internships: Recommendations for improving upon experiential learning. Journal of Hospitality Leisure Sport \& Tourism Education, 22, 75-81. h ttps://doi.org/10.1016/j.jhlste.2018.02.001

Chen, M. C., Liu, Q. L. (2016). Blow-up criteria of smooth solutions to a 3D model of electro-kinetic fluids in a bounded domain, Electronic Journal of Differential Equations, 2016(128), 1-8.

Chen, M. C., Lu, Q., Liu, Q. L. (2018). Global regularity for a 2D model of electro-kinetic fluid in a bounded domain[J]. Acta Mathematicae Applicatae Sinica, English Series, 34(2), 398-403. http://dx.doi.org/10.1007/s10255-018-0740-3

Hung, C. M., Huang, I., \& Hwang, G. J. (2014). Effects of digital game-based learning on students' selfefficacy, motivation, anxiety, and achievements in learning mathematics. Journal of Computers in Education, 1(2-3), 151-166. http://dx.doi.org/10.1007/s40692-014-0008-8

Johnson, E. O., Charchanti, A. V., \& Troupis, T. G. (2012). Modernization of an anatomy class: from conceptualization to implementation. a case for integrated multimodal-multidisciplinary teaching. Anatomical Sciences Education, 5(6), 354-366. http://dx.doi.org/10.1002/ase.1296 
Kurpis, L. H., \& Hunter, J. (2017). Developing students' cultural intelligence through an experiential learning activity: A cross-cultural consumer behavior interview. Journal of Marketing Education, 39(1), 30-46. https://doi.org/10.1177/0273475316653337

Lee, C. Y. (2012). Learning-by-doing in r\&d, knowledge threshold, and technological divide. Journal of Evolutionary Economics, 22(1), 109-132. http://dx.doi.org/10.1007/s00191-010-0202-4

Ma, S., Steger, D. G., Doolittle, P. E., \& Stewart, A. C. (2018). Improved Academic Performance and Student Perceptions of Learning Through Use of a Cell Phone-Based Personal Response System. Journal of Food Science Education, 17(1), 27-32. https://doi.org/10.1111/1541-4329.12131

Schaffner, E., Schiefele, U., \& Ulferts, H. (2013). Reading amount as a mediator of the effects of intrinsic and extrinsic reading motivation on reading comprehension. Reading Research Quarterly, 48(4), 369-385. http://dx.doi.org/10.1002/rrq.52

Sung, H. Y., Hwang, G. J., Lin, C. J., \& Hong, T. W. (2017). Experiencing the Analects of Confucius: An experiential game-based learning approach to promoting students' motivation and conception of learning. Computers \& Education, 110, 143-153. https://doi.org/10.1016/j.compedu.2017.03.014

Tang, L. (2016). Exploration on cultivation of critical thinking in college intensive reading course. English Language Teaching, 9(3), 18. http://dx.doi.org/10.5539/elt.v9n3p18

Vandsburger, E., Duncan-Daston, R., Akerson, E., \& Dillon, T. (2010). The effects of poverty simulation, an experiential learning modality, on students' understanding of life in poverty. Journal of Teaching in Social Work, 30(3), 300-316. http://dx.doi.org/10.1080/08841233.2010.497129 